\title{
Overview of Spray Aerosols for Disinfection Against Airborne and Surface Spread of Covid-19
}

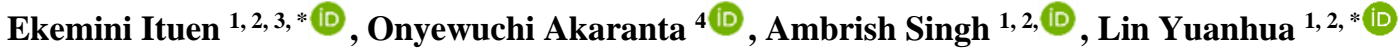 \\ 1 State Key Laboratory of Oil and Gas Reservoir Geology and Exploitation, Southwest Petroleum University, Chengdu \\ 610500, Sichuan, China \\ 2 School of Materials Science and Engineering, Southwest Petroleum University, Chengdu 610500, Sichuan, China \\ 3 Emerging Materials and Energy Research Group, Department of Chemistry, University of Uyo, Uyo, Nigeria \\ 4 African Center of Excellence for Oilfield Chemicals Research, University of Port Harcourt, Port Harcourt, Nigeria \\ * Correspondence: yhlin28@163.com (L.Y.); ekeminiituen@ uniuyo.edu.ng (E.I.);
}

\begin{abstract}
The global outbreak of SARS-Cov-2 (called Covid-19) has claimed many lives, with currently over 59.95 million confirmed cases of infected persons and over 1.4 million deaths worldwide. Spray aerosols used to disinfect areas, surfaces, and objects are crucial to preventing and protecting people against Covid-19. This paper presents and examines various available and approved materials to formulate spray aerosols for disinfection against Covid-19. The formulations are discussed based on the active ingredient and the possible contact time. The virus can be inactivated. The major groups of spray aerosols discussed include quaternary ammonium-based sprays, hydrogen peroxide-based sprays, alcohol-based sprays, acid-based sprays, sodium-based sprays, and other formulations, some of which are recommended by the US Environmental Protection Agency. Information presented here could benefit governments, policymakers, communities, researchers, health workers, and the general public during this pandemic and beyond.
\end{abstract}

Keywords: Covid-19; contact time; formulations; non-toxic; SARS-CoV-2.

(C) 2020 by the authors. This article is an open-access article distributed under the terms and conditions of the Creative Commons Attribution (CC BY) license (https://creativecommons.org/licenses/by/4.0/).

\section{Introduction}

On March 2, 2019, Fan and co-workers published a review that summarized current knowledge on bat transmitted coronavirus [1]. The diversity of the virus, the reservoir hosts, and how the hosts/virus are geographically distributed in China were discussed in the referred work. It provided information for detecting what the authors referred to as 'early warning signs' so that the impact of future outbreaks could be minimized in China. As part of their report, it was predicted that there was a high possibility of a future outbreak of bat caused MERS-like or SARS-like occurring in China. Perhaps, not much attention was paid to coronavirus until in December 2019, when a new pneumonia case of no known cause (yet) broke out in Wuhan, a major town in Hubei Province of China [2, 3]. On successful isolation, a report revealed that it was a severe acute respiratory syndrome coronavirus 2 (SARS-CoV-2), which is different from known respiratory viruses such as avian influenza, SARS-CoV, influenza, and MERS-CoV [2, 4-5]. In response, China took several measures to contain the virus; some of which includes skin investigations, rigorous surveillance, scrutiny at entry ports, treatment of patients that were suspected and/or confirmed, blocking of possible transmission routes, especially by calling on residents to stay at home, use of some antimalarial drugs and by disinfection of streets, 
residences and persons with spray aerosols [6]. Following the outbreak and spread of SARSCoV-2 to other parts of the world, and the associated death toll, World Health Organization (WHO) declared a public emergency on public health (PHEIC) and named the virus Covid-19. As at this time, the total global confirmed cases stands at 59,968,879 with 17,125,307 active cases (99.4\% and $0.6 \%$ in mild and critical conditions, respectively), 41,431,804 recoveries and 1,411,768 deaths. Daily, reports of more deaths and new confirmed cases continue to hit the media, raising fear and panic and putting pressure on technology, medical personnel, isolation facilities, and capacity to combat the virus [7-10]. While reports have it that the situation in China, Italy, and Spain were highly hit, other countries of the world such as USA, Russia, India, Iran, Chile, Saudi Arabia, Pakistan, Qatar, Bangladesh, and Africa are still reporting thousands of new cases daily and many new deaths.

China is popular for first adopting a closure or lockdown and stay-at-home approach to combating Covid-19. However, China had gradually unlocked their system in an attempt to return to normalcy. Several other countries are easing their lockdown measures to give back lives to their citizens. We considered one of the effective methods that could 'trap' and 'possibly kill' the virus before it sticks to humans [11-15]. The use of spray aerosols appears the easiest and most practical approach. Since many countries adopt easing of lockdown in the day and curfew from dusk, the aerosols could be sprayed during the evening tonight to disinfect streets of any 'roaming' strands of Covid-19, in addition to carrying out WHO regulations of washing of hands, social distancing, etc. Families, religious houses, and operators of commercial vehicles, aircraft, and eateries can also spray these aerosols at suitable times to curtail community or contact spreading. Despite that this could be a cheap and pragmatic approach, to the best of our knowledge, little or nothing is reported on the use of spray aerosols for curtailing the spread of Covid-19, hence our motivation for this study. However, there have been several reports on active medications for the treatment of infected patients, which is rather a reactive measure rather than a preventive measure.

Many countries currently 'invaded' by the virus adopt this method for containing the Covid-19. There were videos over social media about sprays used to disinfect streets, residences, and persons in China. Information on the composition of the spray and its formulation is very important to help countries, communities, and individuals join forces to contain Covid-19. However, this information may not be freely available to users, and their use may not be familiar. The possible environmental and health risks associated with some chemicals may not be known. This paper aims to enlighten readers in a summary of sprays' available options, their formulation, and their conditions for efficiency. An effort is made to examine the friendliness of some of the chemicals to humans and environments. Information presented in this paper could benefit governments, policymakers, communities, researchers, health workers, and the general public during this pandemic and beyond.

\section{Aerosols}

Aerosols are colloidal suspensions of particles dispersed in air or gas. In practice, they are often enclosed in a container under pressure and released using propellant as a fine spray. Aerosol sprays for the control of viruses are often classified based on size. Because viruses are typically less than $100 \mathrm{~nm}$ in size, aerosols of greater interests are those with an aerodynamic size smaller than $100 \mathrm{~nm}[16,17]$. Biological particles and fragments such as pollen, bacteria, viruses, and fungi can also be referred to as bioaerosols [18]. In that case, Covid-19 can also be considered as a bioaerosol that is hazardous and contaminates the environment for humans. 
Covid-19 can stay in the air for some time and accelerate transmission; hence using spray aerosols to inactivate them in the air becomes essential [6].

\section{Potential Spray Aerosols for Curtailing Covid-19}

In selecting the type of chemicals for formulating the spray, certain factors need to be considered. Some of them include toxicity and eco-friendliness, $\mathrm{pH}$, temperature and humidity of surroundings, virus persistence, a spray's contact time, etc. [19]. The spray's capability to remain suspended in air or its suspension time under the atmosphere's conditions is also important. This will provide an idea of the frequency of disinfection necessary to surmount the virus completely. Based on the active ingredient in the formulation, we have identified from formulations and brands sold by various companies and recommended by the United States Environmental Protection Agency (USEPA) [6]. These include ammonium-based sprays, hydrogen peroxide-based sprays, alcohol-based sprays, acid-based sprays, and sodium-based sprays. These sprays are often deployed at room temperature.

\subsection{Ammonium based sprays.}

A chemical formulation based on quaternary ammonium salt as an active component developed by Mason Chemicals Company could be a possible spray aerosol for disinfection against Covid-19. Formulated under the product name MAQUAT 50DS, it Alkyl (C14 60\%, C16 30\%, C12 5\%, C18 5\%) dimethyl benzyl ammonium chloride 25\% or Alkyl (C-12 68\%, C-14 32\%) dimethyl ethyl benzyl ammonium chloride 25.0\%. MAQUAT 50DS could be effective within 10 minutes of contact time. Quaternary ammonium compounds have also been popularly used to prepare sanitizers for hands and surface cleaning because of their nontoxicity, low cost, ready availability, and eco-friendliness.

Quaternary ammonium can be formulated with isopropanol because alcohol easily inactivates the virus. Propan-2-ol: $50-100 \% \mathrm{~V} / \mathrm{V}$ mixed with not more than $2 \%$ quaternary ammonium compounds and not more than 5\% Benzyl-C7-17-alkyldimethyl chloride has been claimed to contain the virus within 30 seconds. This product sells as Discide Ultra disinfectant spray by Palermo, Healthcare Limited Liability Company. Isopropanol can be replaced by ethanol as in Wedge disinfectant formulated by North American Infection Control Ltd. Wedge disinfectant is a formulation of $72.5 \%$ ethanol and $0.33 \%$ didecyldimethyl ammonium chloride. It contends the virus within a contact time of 1 minute. Here, isopropanol, which is also a major ingredient in sanitizers, plays the 'killer' role on the virus. Alcohol-based aerosols could be advantageous for their ease of diffusion but could be flammable.

\subsection{Hydrogen peroxide-based sprays.}

Hydrogen peroxide $(0.5 \%)$ may be sprayed directly or as a mixture of $22 \%$ hydrogen peroxide and $15 \%$ peracetic acid. The former is branded as Nathan 2 by S.C. Johnson Professional. It contends the virus within 5 minutes contact time, while the latter is branded as Maguard 1522 by Mason Chemicals Company and contends the virus within 1 minute contact time. Also closely related is the Peraclean 15 by Evonik, which is composed of peroxyacetic acid as an active ingredient. It comprises $14-14 \%$ peracetic acid, 20-30 \% hydrogen peroxide, and $15-20 \%$ acetic acid and contends the virus within 1 minute contact time. Hydrogen peroxide $(3.3 \%)$ may also be mixed with ammonium carbonate and ammonium bicarbonate $(1.3 \%)$ to form a spray aerosol for disinfection of Covid-19 invaded the air. This formulation 
(called Victor spray) by Kimberly-Clark Global Sales Limited Liability Company can contend with the virus for 5 minutes.

The advantage of hydrogen peroxide-based sprays is that the active ingredient (hydrogen peroxide) is not by itself toxic. It is a colorless and non-flammable gas, but being a good oxidizer, it may ignite some organic matter when it comes in contact with it. Hydrogen peroxide-based sprays would be best deployed. Humans are not expected to pass at least within 3- 7 hours after spraying. When the aerosols come in contact with the eyes, it can cause redness or stinging but may not injure the eyes. However, high concentrations of hydrogen peroxide may cause eye ulcers or perforate the eyes, leading to permanent eye injury or even blindness.

Sprays like Nathan 2 may be only recommended for night disinfection. If sprayed in the daytime and sunlight, ultraviolet rays of the sun can catalyze hydrogen peroxide's fast decomposition into water and oxygen, thereby declining the spray's effectiveness in contending the virus. Also, for domestic or laboratory preparation, care should be taken to avoid direct hydrogen peroxide exposure. Hydrogen peroxides sold in transparent glass containers should not be patronized; rather, only those in amber-colored (brown) vessels should be purchased.

\subsection{Alcohol-based sprays.}

Alcohols are not friends to coronavirus at all - it kills the virus within a very short time. Alcohol-based sprays are perhaps the most effective for contending Covid-19. However, alcohol with high purity is very expensive, and their application as spray aerosols could compete with food and fuel. A mixture of $15-30 \%$ ethanol with $15-32 \%$ butane and 5-10\% propane as well as 5-10\% 2, 2-(ethylene dioxy) diethanol can kill Covid-19 strands in the air within 30 seconds contact time. Reckitt Benckiser sells this formulation under the trade name Lysol Neutra Air. It may have a characteristic smell and may be inflammable due to butane and propane, combustible alkanes with odor. Because of these alkanes, this spray is recommended for night disinfection, and reasonable time should be allowed after disinfection before humans can pass or occupy the sprayed region. A phenolic-based spray prepared by a combination of 3.03\% Ortho-benzyl-parachlorophenol and $3.40 \%$ Orthophenyl phenol (trade name: wex-cide 128) by Wexford Labs Inc. can also destroy the virus within 10 minutes contact time.

\subsection{Acid-based sprays.}

A mixture of about $5 \%$ citric acid and $0.003 \%$ silver ion (trade name: Sdc3a) can also be used as spray aerosol for contending Covid-19. Silver ions are known to be toxic to a wide spectrum of microorganisms such as bacteria, protozoa, fungi, and viruses [20, 21]. In combination with citric acid, the formulation destroys the virus within 1 minute contact time. However, fine particles of silver dispersed should not be inhaled because silver ions are associated with pulmonary toxicity $[22,23]$. Where necessary, such sprays should be carried out in the night and a handful of time allowed before human activities return to the disinfected area.

5-10\% octanoic acid called 65 Disinfecting Heavy Duty Acid Bathroom Cleaner prepared by Ecolab Inc. is also an alcohol-based spray aerosol that can contend the virus within 2 minutes contact time. Also, $0.017 \%$ hypochlorous acid called Cleansmart prepared by Simple Science Ltd can destroy the virus within 10 minutes. Suppose the concentration is increased slightly above $0.02 \%$. In that case, very high efficacy could be obtained at a very short exposure 
time. However, toxicity to humans and corrosivity to metal surfaces would result. Acid-based sprays are not popularly used because acids are corrosive and also expensive.

\subsection{Sodium based sprays.}

Sodium chloride $(30.5 \%)$ is a useful spray aerosol designed by Odorstat Limited Liability Company with the trade name Performacide. The estimated contact time for contending the virus is 10 minutes. Sodium chlorite has low toxicity at small doses, can be readily obtained at a reasonable cost, and small does are environmentally friendly. $6.0 \%$ sodium hypochlorite, also known as Austin A-1 Ultra Disinfecting Spray, formulated by James Austin Company, is another spray aerosol that can also destroy the virus within 10 minutes of contact time. When mixed with $1.0 \%$ sodium carbonate, only $4.0 \%$ of sodium hypochlorite can afford very high efficacy and destroys the virus within 30 seconds. This mixture is associated with W.M. Barr and Company Inc. under the trade name Mold Amor Formula 400.

\subsection{Other sprays for disinfection.}

Although branded, there are some other registered disinfectants under the US Environmental Protection Agency (EPA) ${ }^{a}$ list, and they are listed below:

- Clorox Multi-Surface Cleaner + Bleach

- Clorox Disinfecting Wipes

- Clorox Commercial Solutions ${ }^{\circledR}$ Clorox ${ }^{\circledR}$ Disinfecting Spray

- Lysol brand Heavy-Duty Cleaner Disinfectant Concentrate

- Lysol Disinfectant Max Cover Mist

- Lysol brand Clean \& Fresh Multi-Surface Cleaner

- Purell Professional Surface Disinfectant Wipes

- Sani-Prime Germicidal Spray

\subsection{Mechanistic consideration.}

Ethanol and isopropanol have shown high efficacy for destroying Covid-19 when used as sprays and as sanitizers without consequential negative toxic effects on humans. Though alcohols inactivated the virus within a very short time, nothing seems to be known about the mechanism of action. Pradhan and co-workers suggested the ethanol may have acted by precipitated the virus surface protein resulting in its inactivation or destruction [6]. For quaternary ammonium compounds, the presence of $4^{\circ}$ nitrogen elicits a cationic character on the center. Being surrounded with negatively charged nonpolar lipophilic tails that act as surfactants, these tails could elicit a high affinity to the viral cells (being lipids).

Thus, the tails' surface activities on the viral cells cause enhanced permeation into the viral structure and consequential damage of the cell. The tails' antimicrobial/antiviral activity would depend on their basicity, nuclear size, and lipophilicity [24]. Chlorites are commonly known for their antimicrobial effects in lipid environments [25, 26], which justifies their widespread application in disinfectants and domestic cleaning formulations. In terms of high antimicrobial activity, $\mathrm{HOCl}$ is highly potent compared to $\mathrm{NaOCl}$. Both could bind to the virus's lipid membrane, permeate into the cell, disrupt cell activity, and compromise cell integrity. The oxidizing action of hypochlorous acid could make it even more destructive to the virus. For hydrogen peroxide-based aerosols, activity towards the virus could generate free 
radicals, possibly, hydrogen peroxide radicals, peroxyl ion, and/or hydroxyl ion, which oxidize the lipids of the virus surface and possibly compromise the integrity of the viral nucleic acids. The inactivation time for all sprays could be affected by temperature, wind, and relative humidity regimes [27].

\subsection{Sustainability and market potentials.}

As described in the sections above, the main ingredients of spray aerosols that could exhibit antiviral activity towards Covid-19 are quaternary ammonium compounds, alcohols (isopropyl alcohol, phenol, ethanol), acids (octanoic, hypochlorous, citric acid conjugate with silver ions), and some sodium compounds (bicarbonate, hypochlorite). These materials are of low toxicity and considerably inexpensive. Most of them are readily obtainable from chemical stores globally and are fine chemicals with sustainable supply. Therefore, governments of developing countries could channel resources into establishing industries that manufacture these chemicals. Apart from their potential applicability in spray disinfectants for Covid-19, these chemicals will still be useful for various other purposes even in post-Covid-19 era.

\section{Conclusions}

Spray aerosol based on active ingredients such as quaternary ammonium-based sprays, hydrogen peroxide-based sprays, alcohol-based sprays, acid-based sprays, and sodium-based sprays are effective for contending Covid-19. If properly formulated and used to disinfect Covid-19 infested area or surface, these formulations can inactivate the virus within contact times ranging from 30 seconds to 10 minutes. These formulations could be deployed as described for practical disinfection purposes.

\section{Funding}

This research received no external funding.

\section{Acknowledgments}

The authors are grateful to Kokoette Raymond and Ekere Ekemini for their assistance.

\section{Conflicts of Interest}

The authors declare no conflict of interest.

\section{References}

1. Fan, Y.; Zhao, K.; Shi, Z.L.; Zhou, P. Bat Coronaviruses in China. Viruses 2019, 11, http://doi.org/10.3390/v11030210.

2. $\quad$ Li, Q.; Guan, X.; Wu, P.; Wang, X.; Zhou, L.; Tong, Y.; Ren, R.; Leung, K.S.; Lau, E.H.; Wong, J.Y.; Xing, $\mathrm{X}$. Early transmission dynamics in Wuhan, China, of novel coronavirus-infected pneumonia. New England Journal of Medicine 2020, 382, 1199-1207, http://doi.org/10.1056/NEJMoa2001316.

3. Sarkodie, S.A.; Owusu, P.A. Investigating the cases of novel coronavirus disease (COVID-19) in China using dynamic statistical techniques. Heliyon. 2020, https://doi.org/10.1016/j.heliyon.2020.e03747.

4. Gorbalenya, A.E. Severe acute respiratory syndrome-related coronavirus e the species and its viruses, a statement of the coronavirus study group. Nature Microbiology 2020, 5, 536-544, http://doi.org/10.1038/s41564-020-0695-Z.

5. Zhu, N.; Zhang, D.; Wang, W.; Li, X.; Yang, B.; Song, J.; Zhao, X.; Huang, B.; Shi, W.; Lu, R.; Niu, P. A novel coronavirus from patients with pneumonia in China, 2019. New England Journal of Medicine 2020, 382, 727-733, http://doi.org/10.1056/NEJMoa2001017. 
6. Pradhan, D.; Biswasroy, P.; Ghosh, G.; Rath, G. A Review of Current Interventions for COVID-19 Prevention. Archives of Medical Research 2020, 51, 363-374, https://doi.org/10.1016/j.arcmed.2020.04.020.

7. Aleta, A.; Moreno, Y. Evaluation of the potential incidence of COVID-19 and effectiveness of containment measures in Spain: a data-driven approach. BMC Medicine 2020, 18, 1-2, https://doi.org/10.1186/s12916020-01619-5.

8. Bénassy-Quéré, A.; Marimon, R.; Pisani-Ferry, J.; Reichlin, L.; Schoenmaker, D.; Weder, B. COVID-19: Europe needs a catastrophe relief plan. In: Mitigating the COVID Economic Crisis: Act Fast and Do Whatever. Repository.graduateinstitute.ch.

9. Lau, H.; Khosrawipour, V.; Kocbach, P.; Mikolajczyk, A.; Ichii, H.; Schubert, J.; Bania, J.; Khosrawipour, T. Internationally lost COVID-19 cases. Journal of Microbiology, Immunology and Infection 2020, 53, 454458, https://doi.org/10.1016/j.jmii.2020.03.013.

10. Shim, E.; Tariq, A.; Choi, W.; Lee, Y.; Chowell, G. Transmission potential and severity of COVID-19 in South Korea. International Journal of Infectious Diseases. 2020, 93, 339-344, https://doi.org/10.1016/j.ijid.2020.03.031.

11. Huang, Z.; Zhao, S.; Li, Z.; Chen, W.; Zhao, L.; Deng, L.; Song, B. The battle against coronavirus disease 2019 (COVID-19): emergency management and infection control in a radiology department. Journal of the American College of Radiology 2020, 17, 710-716, https://doi.org/10.1016/j.jacr.2020.03.011.

12. Liu, Q.; Liu, Z.; Zhu, J.; Zhu, Y.; Li, D.; Gao, Z.; Zhou, L.; Yang, J.; Wang, Q. Assessing the Global Tendency of COVID-19 Outbreak. MedRxiv 2020, https://doi.org/10.1101/2020.03.18.20038224.

13. Lu, D.; Wang, H.; Yu, R.; Yang, H.; Zhao, Y. Integrated infection control strategy to minimize nosocomial infection of coronavirus disease 2019 among ENT healthcare workers. The Journal of Hospital Infection 2020, 104, 454-455, https://doi.org/10.1016/j.jhin.2020.02.018.

14. Wu, Y.; Huang, X.; Jiang, Z.; Liu, S.; Cui, L. Composition and sources of aerosol organic matter in a highly anthropogenic influenced semi-enclosed bay: Insights from excitation-emission matrix spectroscopy and isotopic evidence. Atmospheric Research 2020, 241, https://doi.org/10.1016/j.atmosres.2020.104958.

15. Rothan, H.A.; Byrareddy, S.N. The epidemiology and pathogenesis of coronavirus disease (COVID-19) outbreak. Journal of Autoimmunity 2020, 109, https://doi.org/10.1016/j.jaut.2020.102433.

16. Pease, L.F.III. Physical analysis of virus particles using electrospray differential mobility analysis. Trends in Biotechnology 2012, 30, 216-224, https://doi.org/10.1016/j.tibtech.2011.11.004.

17. Yu, H.; Afshar-Mohajer, N.; Theodore, A.D.; Lednicky, J.A.; Fan, Z.H.; Wu, C.Y. An efficient virus aerosol sampler enabled by adiabatic expansion. Journal of Aerosol Science 2018, 117, 74-84, https://doi.org/10.1016/j.jaerosci.2018.01.001.

18. Hyun, J.; Lee, S.G.; Hwang, J. Application of corona discharge-generated air ions for filtration of aerosolized virus and inactivation of filtered virus. Journal of Aerosol Science 2017, 107, 31-40, https://doi.org/10.1016/j.jaerosci.2017.02.004.

19. Kampf, G. Potential role of inanimate surfaces for the spread of coronaviruses and their inactivation with disinfectant agents. Infection Prevention in Practice 2020, 2, https://doi.org/10.1016/j.infpip.2020.100044.

20. Greulich, C.; Braun, D.; Peetsch, A.; Diendorf, J.; Siebers, B.; Epple, M.; Köller, M. The toxic effect of silver ions and silver nanoparticles towards bacteria and human cells occurs in the same concentration range. RSC Advances 2012, 2, 6981-6987, https://doi.org/10.1039/C2RA20684F.

21. Vazquez-Muñoz, R.; Borrego, B.; Juárez-Moreno, K.; García-García, M.; Morales, J.D.; Bogdanchikova, N.; Huerta-Saquero, A. Toxicity of silver nanoparticles in biological systems: does the complexity of biological systems matter? Toxicology Letters 2017, 76, 11-20, https://doi.org/10.1016/j.toxlet.2017.05.007.

22. Drake, P.L.; Hazelwood, K.J. Exposure-related health effects of silver and silver compounds: a review. The Annals of Occupational Hygiene 2020, 49, 575-585, https://doi.org/10.1093/annhyg/mei019.

23. Hadrup, N.; Anoop, K.; Sharma, K.; Loeschner, K.; Jacobsen, N.R. Pulmonary toxicity of silver vapours, nanoparticles and fine dusts: A review. Regulatory Toxicology and Pharmacology 2020, 115, https://doi.org/10.1016/j.yrtph.2020.104690.

24. Requião, R.D.; Carneiro, R.L.; Moreira, M.H.; Ribeiro-Alves, M.; Rossetto, S.; Palhano, F.L.; Domitrovic, T. Viruses with different genome types adopt a similar strategy to pack nucleic acids based on positively charged protein domains. Scientific Reports 2020, 10, 1-2, https://doi.org/10.1038/s41598-020-62328-w.

25. Allende, A.; McEvoy, J.; Tao, Y.; Luo, Y. Antimicrobial effect of acidified sodium chlorite, sodium chlorite, sodium hypochlorite, and citric acid on Escherichia coli O157: H7 and natural microflora of fresh-cut cilantro. Food Control. 2009, 20, 230-234, https://doi.org/10.4315/0362-028X-63.8.1087.

26. Quilo, S.A.; Pohlman, F.W.; Dias-Morse, P.N.; Brown, A.H.; Crandall, P.G.; Baublits, R.T.; Aparicio, J.L. The impact of single antimicrobial intervention treatment with potassium lactate, sodium metasilicate, peroxyacetic acid, and acidified sodium chlorite on non-inoculated ground beef lipid, instrumental color, and sensory characteristics. Meat Science 2009, 83, 345-350, https://doi.org/10.1016/j.meatsci.2009.05.015.

27. Feng, Y.; Marchal, T.; Sperry, T.; Yi, H. Influence of wind and relative humidity on the social distancing effectiveness to prevent COVID-19 airborne transmission: A numerical study. Journal of Aerosol Science 2020, 147, https://doi.org/10.1016/j.jaerosci.2020.105585. 